\title{
$21: 45165232-45130314$
}

National Cancer Institute

\section{Source}

National Cancer Institute. 21:45165232-45130314. NCI Thesaurus. Code C45090.

Physical location of IT GB2_Gene 